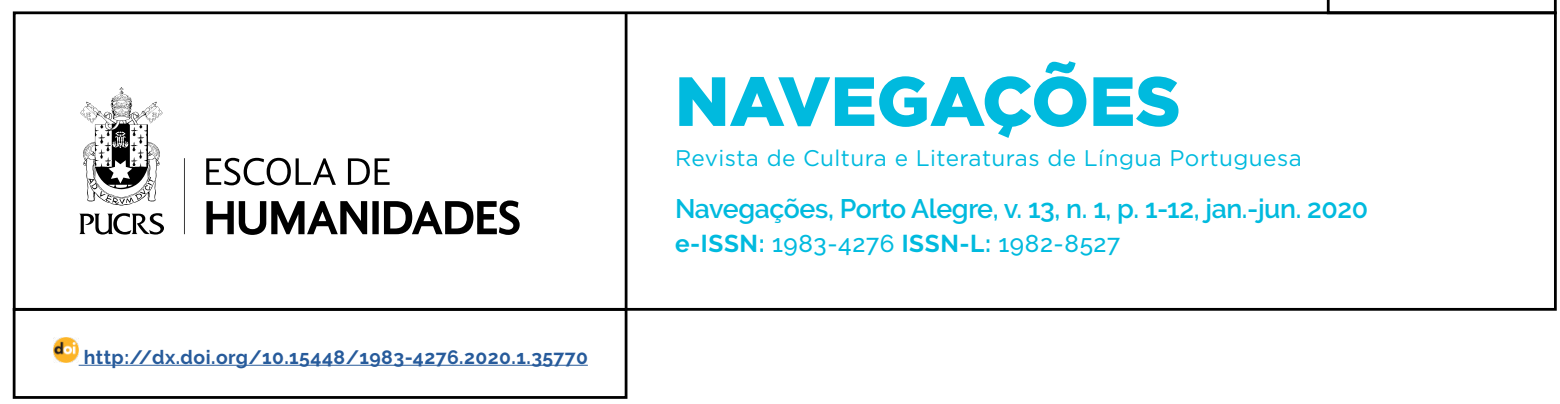

SEÇÃO: ENSAIOS

\title{
Vladimiro Caposso, o "homem novo": considerações sobre a distopia pós-revolucionária em Predadores, de Pepetela
}

\author{
Vladimiro Caposso, the "new man": considerations about the post-revolutionary \\ dystopia in Predators, by Pepetela
}

\section{Mariana Sousa Dias ${ }^{1}$ \\ orcid.org/0000-0001-6411-024X \\ marianasousadias@yahoo.com.br}

Recebido em: 23 set. 2019.

Aprovado em: 23 mar. 2020 Publicado em: 10 ago. 2020.

\section{(c) (1)}

Artigo está licenciado sob forma de uma licença Creative Commons Atribuicãa 4.0 Internacional.
Resumo: O presente trabalho aborda a oposição entre o homem novo angolano, idealizado durante as lutas de libertação, frente à ascensão do novo homem angolano, forjado a partir de valores capitalistas no romance Predadores, de 2005. Os tensionamentos delineados pela conjugação utopia-distopia, ou seja, homem novo-novo homem, traduzem, em boa medida, não somente as problemáticas enfrentadas por Angola na atualidade, mas o elemento central da atuação literária de Pepetela: a busca por identificações a serem pensadas a partir das falhas que marcam os dois modelos subjetivos - bem como as interpretações e adaptações realizadas a partir de tais perfis. Para estudarmos a obra, recorreremos em especial a Fanon (1979), Frade (2007) e Mudimbe (2012). Palavras-chave: Literatura. Pepetela. Angola. Predadores.

Abstract: This work addresses the opposition between the Angolan new man idealized during the liberation struggles, against the rise of the new Angolan man, forged from capitalist values in the 2005 novel "Predadores". The tensions outlined by the utopia-dystopia conjugation, ie, new man-new man, translate, to a good extent, not only the problems facing Angola today, but also the central element of Pepetela's literary activity: the search for identifications to be thought from the failures that mark the two subjective models - as well as the interpretations and adaptations made from such profiles. To study the work, we will resort in particular to Fanon (1979), Frade (2007) and Mudimbe (2012).

Keywords: Literature. Pepetela. Angola. Predators.

\section{Introdução}

Sabe-se que os processos de globalização do século XX tiveram forte impacto sobre as nações egressas do colonialismo europeu, colocandoas diante de fronteiras transnacionais e essencialmente hibridas. São inúmeros os debates voltados às formulações identitárias angolanas após a conquista da independência, visto que envolvem uma série de práticas, discursos e estratificações:

A independência dos estados africanos esgotou o anterior filão e, em consequência, arrastou outras temáticas mais ajustadas às novas realidades. Os temas em voga são agora outros. O combate é muito diferente. A ameaça já não está no colonizador, na falta de afirmação de uma identidade nacional, mas na necessidade de criar uma nova utopia. Uma sociedade mais justa, baseada na igualdade de oportunidades e de direitos. A denúncia da corrupção tornou-se uma necessidade imperiosa e foi ganhando expressão crescente (FRADE, 2007, p. 15). 
Nesse sentido, é consideravelmente proficua a análise da representação do fluxo utopia-distopia na escrita de Pepetela. Nas obras do autor, as referências à subversão dos ideais socialistas por boa parte dos governos africanos são essenciais para uma leitura eficiente da situação pós-revolucionária angolana, visto que os abusos de poder, o descompasso entre ideologia e atuação política.

Interessa-nos analisar, no romance Predadores, publicado em 2005, a transposição metafórica da passagem do "homem novo" angolano, projetado com base nos ideais marxistas, para o "novo homem" angolano, forjado pelas demandas capitalistas que orientam as dinâmicas da globalização. Organizada em vinte capítulos, a obra leva-nos à luta pelo poder na Angola livre a partir da trajetória do rico empresário Vladimiro Caposso, de novembro de 1974 até dezembro de 2004. É fundamental ressaltarmos que a obra se inicia em 1992, mesmo ano em que a narrativa de A geração da utopia tem seu desfecho: a incerteza das possibilidades levantadas por

Predadores acaba por descortinar, assim, um olhar desencantado quanto aos rumos do país.

Os questionamentos levantados por Predadores, quanto à passagem do periodo colonial ao pós-colonial, voltam-se a uma complexa análise dos agentes, dos fatores contextuais e das fraturas ideológicas que marcam a transição política, aproximando-se, portanto, das reflexões apresentadas pelo filósofo camaronês Achille Mbembe. Segundo o pesquisador:

Para muitos agentes da época colonial, tratava-se definitivamente de um combate maniqueista. [...] Cinquenta anos depois, que vestígios, marcas e resquícios subsistem dessa experiência de sublevação, da paixão que a inflamou, dessa tentativa de passagem do estado de coisa ao estado de sujeito da vontade de retomar a "questão do homem"? Haverá, realmente, algo a comemorar ou, pelo contrário, é necessário recomeçar? Recomeçar o quê, por que, como e em quais condições? (MBEMBE, 2014, p. 22).

Cabe pontuar que a ironia é um dos principais recursos utilizados pelo autor para apresentar os impactos da globalização e do avanço capitalista sobre a sociedade angolana. Reconhecê-la como chave de leitura é imprescindivel para o entendimento de uma crítica que não se limita à ação de outros países sobre Angola, mas também sobre as relações perniciosas estabelecidas internamente, pois:

É cada vez mais pertinente a distinção analítica em dois niveis: a África conjuntural, de ondas curtas, episódica, referida a grupos particulares e aos seus interesses e a África na longa duração, de construção e gestão da heterogeneidade étnica e cultural. A primeira caracteriza-se por uma debilidade econômica, instabilidade politica e relativa marginalização na cena internacional. A segunda se assenta na história profunda de África, isto é, a história que realiza o presente com o passado colonial e pré-colonial, numa análise prospectiva e da conjunção da tradição e da modernidade (GONÇALVES, 2005, p. 182-183).

Ao considerarmos essa conjunção, no que diz respeito às configurações da sociedade angolana após a independência, o título da obra ganha especial sentido, visto que a predação abordada não enfoca as selvas africanas, como reforçam as cristalizadas visões sobre o continente, mas sim as relações interpessoais: em Predadores, conforme indica a clássica frase de Plauto, "o homem é o lobo do homem" (PLAUTO apud PEPETELA, 2008, p. 136); a desumanização marca o abandono dos pressupostos éticos e as relações de dominação do povo angolano são propiciadas por toda sorte de subterfúgios e ações ilícitas. Assim, a analogia traz à tona a zoomorfização da emergente burguesia angolana, que devora os recursos nacionais por meio de atos ilícitos, incondizentes com os ideais igualitários pregados durante as lutas de libertação.

Para caracterizar as feições capitalistas em Angola, o narrador do romance afirma que:

Com esse regime não havia perigo de obesidade, mal da civilização atual, dirão alguns mais cínicos, preocupados que sigamos os padrões de alimentação e vício impostos pela cultura dos norte-americanos. Estamos mesmo mal, se já o arroz ou a batata importada ficam mais barato que a nossa farinha de mandioca, principal comida dos antepassados. ISe houver ocasião, talvez mais tarde se trate dessas árduas e estéreis questões econômicas, com fortes conotações politicas] (PEPETELA, 2008, p. 42-44). 
O trecho evidencia-nos (não somente por apresentar de forma sarcástica a fome, mas também o encarecimento dos alimentos nacionais) uma denúncia da naturalização de tais problemas como consequências irreversiveis da ascensão capitalista. O narrador nos insere, assim, em uma cruel dinâmica, ironicamente delineada ao longo de todo o romance por meio da representação da cadeia predatória, que tem como seu representante máximo Caposso, criatura desprovida de senso ético, empatia ou mesmo afeto, visto que demonstra algum carinho apenas pela filha Mireille, enquanto a jovem demonstrava aptidão para seguir os seus passos na carreira empresarial.

Somos apresentados a Vladimiro no ano de 1991, como um misterioso homem que, no cenário turbulento de uma Angola agitada pela disputa política, assassina a amante que o estava traindo:

Faltava uma semana para as eleições [...]. Caposso apontou com frieza do lado de fora do quarto, retendo a respiração, como aprendera da arte de bem disparar. Esvaziou o carregador da pistola. Os tiros foram bastante abafados pelo barulho atroador da carreata. Entrou no quarto, empurrou com o cano da pistola o corpo do homem morto. Verificou que ela também estava morta, três buracos perto do coração. Não era por eles que fazia essa matança, era por si próprio. Saiu do quarto, guardou a arma, foi à mesa da sala onde sabia haver sempre marcadores e canetas. Com uma caneta de feltro vermelha, escreveu numa folha de papel em maiúsculas e com a mão esquerda "Ninguém trai a UNITA sem deixar a vida" (PEPETELA, 2008, p. 15-17).

Ao optar por iniciar o livro a partir desse episódio, o autor propõe que nos deparemos com Caposso no auge do seu poder predatório, em uma explanação de seu caráter oportunista e cruel diante do cenário marcado pela guerra civil. O personagem, conforme nos indica o trecho, aproveita-se deliberadamente de um grave momento de tensão política para realizar seus caprichos. O "homem de impecável fato azul" (PEPETELA, 2008, p. 15), conforme se revela em seguida, é um importante empresário angolano que, em variadas ocasiões, age como um inimigo da pátria, utilizando-se da posição privilegiada para agir inescrupulosa e impunemente. Suas origens, nos capítulos seguintes, são apresentadas ao leitor.

Vladimiro Caposso, antes José, nasceu em 1954 no Calulo, região pobre, onde cursou o primário. Seu pai atuava como enfermeiro de forma irregular, trabalhando sem diploma e por conta própria nas diferentes localidades que percorreu, do Cuanza-Sul a Novo Redondo, capital do distrito. Decidiu abandonar a mãe de José quando o menino tinha oito anos, levando-o consigo, em uma espécie de fuga para não ter de pagar reparações e desagravos à família da mulher abandonada.

Aos dezesseis anos, seguindo os conselhos paternos, José desistiu de estudar e desejava ser jogador de futebol:

O progenitor do menino José nem queria ouvir falar de alguns raros nomes de africanos que tinham conseguido singrar no futebol europeu. Ele era enfermeiro, de fato não era totalmente. apenas ajudante, embora soubesse muito mais que alguns enfermeiros brancos. Nunca seguira o caminho de outros enfermeiros angolanos, muitos dos quais se tinham metido em estudos ou em organizações políticas, conspirando pela independência. Caposso-pai nunca quis saber de estudos ou política. Se te metes em livros e em política acabas na cadeia, por isso Capossofilho não entendia nada de estudos e de política, queria apenas ser futebolista (PEPETELA, 2008, p. 70).

Quando seu pai faleceu, vítima de um colapso, em Porto Amboim, o protagonista tinha dezoito anos. Sem objetivos de vida definidos, chegou a Luanda aos vinte anos de idade. Lá, reencontrou por acaso Sebastião Lopes, conhecido de Novo Redondo que desejava lutar pela independência do país. Sebastião Lopes é descrito pelo narrador como um jovem puro que "desejava se inscrever nas Forças Armadas Pela Libertação de Angola (FAPLA), fazer treino militar, lutar pelo pais" (PEPETELA, 2008, p. 98).

O jovem levou-o à presença de Seu Amilcar, português proprietário de uma modesta loja que necessitava de um empregado. Como vendedor, José aprendeu a desenvolver habilidades de persuasão que seriam muito valiosas futuramente: 
José tinha facilidade de expressão, o que descobrira com Sô Amílcar, tens boa lábia, engana muito bem, Lhe dizia ele [...]. Talvez era a voz convincente que fazia, parecia sempre estar a dizer a verdade mais profunda do universo, tal a convicção ele punha nas palavras, olhando descaradamente nos olhos opostos. Qualidade que iria mais tarde aperfeiçoar, treinando à frente do espelho. A grande cidade era uma verdadeira escola, a cada dia descobria muita coisa nova (PEPETELA, 2008, p. 80-81)

Uma semana antes da independência, Seu Amílcar comunicou a José que retornaria a Portugal, temeroso em relação às mudanças que provavelmente ocorreriam à "gente de boa-fé que queria fugir sem saber, uns porque temiam represálias em presença do Juizo Final, outros porque temiam represálias dos antigos colonizados, consciências pesando pelos crimes do passado" (PEPETELA, 2008, p. 84). Dessa forma, passaria a ser dono do comércio abandonado.

Inicialmente, Sebastião tenta convencer o amigo a entrar em uma fábrica, para assim se tornar um proletário a serviço da revolução. Caposso recusa as investidas, pois julga ter arranjado com a loja um meio para adquirir bens materiais e capital financeiro. O rapaz critica o protagonista por estar prestes a entrar na pequena burguesia urbana, "a classe do compromisso, que pode lixar a revolução" (PEPETELA, 2008, p. 79).

O desgaste entre Sebastião Lopes e José é fundamental, visto que marca a oposição entre o idealismo do primeiro e a indiferença do segundo quanto aos rumos políticos do país:

Que o tonto sonhador do Sebastião lhe desculpasse, operário não queria ser, mesmo por melhor salário, não gostava do cheiro de máquinas e de andar todo sujo e a fazer constantemente força. [...] Paciência, seria da pequena-burguesia, raio de nome tão feio. E ainda por cima pequena, antes fosse grande! (PEPETELA, 2008, p. 118).

A disposição de José, na contramão daquele momento histórico, se aquecia com o desejo de ser tornar um grande burguês. Contudo, politicamente, os revolucionários guiavam-se pelo viés socialista e condenavam manifestações de tendência liberal. É assumido, a partir desse momento, seu "talento" oportunista. José passa a simbolizar todos os que se aproveitaram do turbilhão inicial para ascenderem socialmente:

Caposso cometeu na noite da independência uma ação que nunca revelou a ninguém, nem ao amigo mais chegado, nem à futura mulher, muito menos aos filhos. Enquanto o povo todo de Luanda, bebês inclusive, se aglomerava na praça onde o presidente, à meia-noite, ia declarar a independência, ele se deixou ficar em casa. Mais tarde, aos amigos, contava como vira subir a bandeira rubro-negra como a tribuna era pequena para todos os que queriam aparecer nas fotos junto do presidente e como ele ficara mesmo perto do mastro onde subira a nossa bandeira (PEPETELA, 2008, p. 91-92).

Mentiras dessa ordem passaram a fazer parte da vida do protagonista, enquanto ia desenrolando os fios de sua personalidade capitalista, até se tornar, em menos de duas décadas, um dos homens mais ricos de Angola. Contrariando o que se esperava daqueles que se compraziam com a libertação, o jovem não fechou o seu comércio na noite da independência, justificando a atitude oportunista como uma demonstração de altruísmo:

Enquanto no 11 de Novembro toda a cidade estava parada, estabelecimentos e comércio fechados, comemorando o facto fundador do novo país, ele abriu a loja. E esta decisão foi questionável porque muitos consideraram falta de respeito aquele patrício não acatar o feriado, aquele feriado sagrado. Mas, por outro lado, as pessoas que assim puderam encontrar um sitio onde comprar a fuba e o peixe seco para celebrar os festejos, agradeceram o sacrifício patriótico de trabalhar enquanto os outros dançavam. Nesse dia ele abriu de facto só de manhã, fechou à tarde. Tinha vendido mais do que nunca, dava para completar a compra de chapas e rodear completamente o quintal, sua única preocupação no momento. Entretanto, de manhã, ouvindo os comentários dos fregueses, quase nenhum tendo dormido, percebia como a política lhe entrava pela porta, mesmo dela querendo sempre fugir (PEPETELA, 2008, p. 56).

Embora desprezando os ideais do amigo Sebastião, não hesita em pedir ao agora guerrilheiro, que vinha da frente de batalha, para 
ser indicado à desejada inscrição no Movimento, argumentando falaciosamente que "o amigo era testemunha, ele sempre tinha tido ideias nacionalistas, um verdadeiro militante, queria ser um homem novo, embora sem andar por aí a gritar aos quatro ventos" (PEPETELA, 2008, p. 131). Diante das evidências da inclinação do amigo para o lado oposto aos interesses coletivos, o revolucionário não apenas se recusa a ajudá-lo a se aproximar do Movimento, como põe fim à amizade até então estabelecida.

Os predadores da nação angolana, representados principalmente por Vladimiro Caposso, correspondem às reflexões de Frantz Fanon quanto à criação da burguesia nacional em Os Condenados da Terra. A análise do pesquisador a respeito da formação das burguesias nacionais das ex-colônias africanas coincide com o ambiente pós-independência apresentado na obra de Pepetela. Para Fanon:

A burguesia nacional, que toma o poder no fim do regime colonial, é uma nova burguesia, uma burguesia subdesenvolvida. Seu poder econômico é quase nulo e de qualquer modo sem medida comum com o da burguesia metropolitana ao qual pretende substituir. Nacionalização, para ela, significa exatamente transferir aos autóctones favores ilegais herdados do periodo colonial (FANON, 2008, p. 124-126)

Analisando criticamente a adoção da ideologia marxista pelos dirigentes africanos, no pósindependência, o filósofo congolês Valentin-Yves Mudimbe informa-nos que "o marxismo parecia corresponder à ferramenta e à ideia perfeitas para transcender aquilo que o colonialismo havia incorporado e decretado em nome do capital" (MUDIMBE, 2012, p. 70). Entendemos, à luz dessas considerações, que os ideais socialistas e o modelo de homem novo, adotados como planos de governo por diversos países africanos, significaram para essas novas nações o cumprimento do que dizia a cartilha marxista ditada pelo bloco cubano-soviético. Eram, também, uma resposta ao ocidente colonizador que, em nome do capital e por ele, dominou e explorou, por largo tempo, as terras e os povos africanos.
Sobre a percepção de um modelo de sujeito, Erich Fromm, psicanalista, sociólogo e filósofo alemão, indica-nos que "a existência empírica do homem é o ponto de partida do marxismo" (FROMM, 1962, p. 33). Dessa forma, o conceito marxista de homem baseia-se na concepção de um ser não apenas formado por características fisiológicas e biológicas, mas composta, sobretudo, de particularidades como consciência, estrutura social e alienação. Assim, "para Marx, o homem revela-se como um ser essencialmente histórico, um ser em eterno tornar-se" (FROMM, 1962, p. 39).

Em A ideologia alemã, o próprio Marx indicanos que:

Pode-se distinguir os homens dos animais pela consciência, pela religião e por tudo o que se queira. Mas eles próprios começam a se distinguir dos animais logo que começam a produzir seus meios de existência, e esse passo à frente é a própria consequência de sua organização corporal. [...] Essas bases do homem são verificáveis por via puramente empírica. A condição de toda história humana é, naturalmente, a existência de seres humanos vivos. A primeira situação a constatar é, portanto, as relações que ele gera entre eles e o restante da natureza. Não podemos fazer aqui um estudo mais profundo da própria constituição física do homem, nem das condições naturais, que os homens encontraram já prontas, condições geológicas, orográficas, hidrográficas, climáticas e outras. Toda historiografia deve partir dessas bases naturais e de sua transformação pela ação dos homens, pelo trabalho, no curso da história (MARX, 1998, p. 45).

Podemos notar que Marx preconiza a necessidade de considerarmos as dinâmicas e demandas sócio-históricas para pensarmos os sujeitos, o trabalho e as possibilidades de transformação, compreendendo os indivíduos dentro de suas condições reais. Devemos considerar, portanto, que Pepetela nos proporciona reflexões não apenas quanto ao conceito marxista de homem, mas, sobretudo, quanto à leitura que os governantes angolanos fizeram de tal proposta.

O primeiro aprendizado de José, no partido, foi o seguinte: "quando for tratar com algum funcionário ou membro do MPLA da situação leve 
a carteira recheada" (PEPETELA, 2008, p. 91). Dessa maneira, diante de um "funcionário desdentado e com cara de muita fome" (PEPETELA, 2008, p. 95) ele facilmente conseguiu o cartão de membro do partido com o nome de Vladimiro Caposso, empregado comercial. Deixou de usar o verdadeiro nome de José, o mesmo do seu pai; trocou a verdadeira cidade de nascimento, Calulo, por Catete, a cidade onde nascera Agostinho Neto. De maneira essencialmente irônica, o narrador nos diz que Caposso criou

[...] uma assinatura revolucionária, capaz de fazer inveja àqueles heróis vindos da mata. Vladimiro Caposso, VC, explicando para quem não sabia que não só era o seu nome mas como VC significava também a Vitória é Certa, principal palavra de ordem do MPLA, que inspirara o nome do jornal do Movimento e cujas iniciais, ditas em inglês, $\mathrm{ViCi}$, eram o nome da principal base na Zâmbia, nos tempos da luta de libertação (PEPETELA, 2008, p. 95).

Oficializava-se, assim, o surgimento do novo Vladimiro Caposso: era o último descendente de uma familia que, por conta das perseguições do poder colonial, espalhou-se por todo o país; o avô e o pai foram perseguidos por serem enfermeiros, "classe revolucionária por excelência" (PEPETELA, 2008, p. 96). Para escaparem, viviam mudando de nome e de lugar, talvez o Caposso fosse "nome de clandestinidade" (PEPETELA, 2008, p. 96).

Por meio da articulação entre ficção e história operada por Pepetela, o processo de independência torna-se um divisor de águas para Angola e para Vladimiro Caposso. De simples ajudante de um comerciante português, em 1974. Vladimiro torna-se um verdadeiro alpinista social:

A burguesia nacional é desde o início orientada para atividades de tipo intermediário. A base de seu poder reside em seu senso do comércio e dos pequenos negócios, em sua aptidão para angariar comissões. Todas as vezes que esse processo foi adotado observou-se que o poder tinha de fato contribuido para o triunfo de uma ditadura de funcionários formados pela antiga metrópole que logo se revelavam incapazes de pensar na totalidade da nação. Esses funcionários começam bem depressa a sabotar a economia nacional, a desconjuntar os organismos, e a corrupção, a prevaricação, a dilapidação dos estoques. Os governantes supostamente marxistas assumiram práticas capitalistas de depredação (FANON, 1979, p. 148).

A evolução do nacionalismo angolano foi caracterizada como a expressão de um sentimento de repúdio a Portugal e, fundamentalmente, ao controle exercido pelos ocidentais sobre todas as esferas sociopolíticas, culturais e econômicas de suas colônias. Vários fatores contribuíram para os processos de formação, evolução e sistematização dos movimentos emancipatórios, destacando-se o fortalecimento das elites intelectuais, em especial a partir das décadas de 40 e 50 do século XX.

Em contato com grandes ideais de liberdade circulantes no exterior, grupos de estudantes angolanos em Portugal constituiram importantes espaços de reflexão, onde se discutiam temas relativos às identidades "ex-cêntricas". Dentre tais associações, destaca-se a Casa dos Estudantes do Império, "lugar de muitas discussões sobre a questão colonial e a decorrente situação dos países colonizados" (CHAVES, 1999, p. 43).

A independência foi proclamada em 1975. Com aquele ato, o Movimento Pela Libertação de Angola passava de grupo libertador para o partido dirigente e criador de um Estado. Nesse sentido, o sistema político da Angola pós-independente é inspirado na forma de governo comunista-leninista, com a forte atuação centralizadora de um partido único. O ideal do homem novo, assim, era pensado pela intelectualidade que participava da empreitada revolucionária, porém, não era compreendido de fato por grande parte da população:

O discurso dos primeiros anos após a independência, em Angola, caminhava no sentido da criação de uma Cultura Nova, intentando alcançar a unidade nacional através da uniformização dos atos culturais. Este ideal ficou expresso na palavra de ordem: "Angola, de Cabinda ao Cunene, um só povo, uma só nação". Este homem angolano é, na verdade, um homem novo, adequado aos princípios adotados pelo Estado. Este homem novo deveria ser o fio condutor para o estabelecimento de uma nova sociedade, assentada em novos 
propósitos: não poderia ser um homem reacionário, entendido aqui como tendo enraizada as suas particularidades étnicas ou regionais; nem mesmo ser um assimilado, produto da política colonial (ARAÚJO, 2005, p. 123).

O ideal de um homem novo para uma nação nova tornou-se, portanto, um dos pilares do período revolucionário, visto que traria os princípios básicos que norteariam a composição do sujeito pós-independência ideal. Com letra de Manuel Rui, o Hino Nacional de Angola, adotado em 1975, dá relevância a tal figura:

Angola Avante!

Oh, Pátria, nunca mais esqueceremos

Os heróis do quatro de Fevereiro.

Oh, Pátria, nós saudamos os teus filhos

Tombados pela nossa Independência.

Honramos o passado e a nossa História,

\section{Construindo no trabalho o Homem Novo,}

Angola, avante!

Revolução, pelo Poder Popular!

Pátria Unida, Liberdade,

Um só povo, uma só Nação!

Levantemos nossas vozes libertadas

Para glória dos povos africanos.

Marchemos, combatentes angolanos,

Solidários com os povos oprimidos.

Orgulhosos lutaremos pela paz

Com as forças progressistas do mundo (RUI, [1975], grifo nosso).

No discurso da Proclamação de Independência, feito por Agostinho Neto em 11 de novembro de 1975, também é possível encontrar o homem novo, símbolo da renovação de Angola e do enfrentamento das limitações coloniais:

Derrotado o colonialismo, reconhecido o nosso direito à independência que se materializa neste momento histórico, está realizado o programa mínimo do MPLA. Assim nasce a jovem República Popular de Angola, expressão da vontade popular e fruto do sacrifício grandioso dos combatentes da libertação nacional. Porém, a nossa luta não termina aqui. O objetivo é a independência completa do nosso País, a constru- ção de uma sociedade justa e de um Homem Novo (NETO, [1975]).

Para além do projeto unificador, notase em tal postura uma perigosa tendência à homogeneização dos sujeitos angolanos, a despeito da considerável diversidade étnica, regional e racial presente do país. O preceito central de tais deambulações seria, portanto, a formulação de uma de identidade que pudesse despertar a consciência nacional, como via de fortalecimento da verve revolucionária que se buscava contrapor aos processos assimilatórios que persistiram (e ainda persistem, sob diversas facetas) durante séculos de dominação portuguesa. Com a permanência fortalecida de Agostinho Neto como presidente, a defesa de um ideal de homem novo, que simultaneamente seria um intelectual e um combatente, é considerada elemento essencial para a posterior estabilização dos quadros de governo.

Tais deliberações deixam claras as facilidades encontradas por Caposso para adequar-se ao modelo de homem novo, sem, no entanto, sêlo ideologicamente. Como membro do Comitê Central da Jota, participou de um congresso do MPLA contra um membro honesto do partido, para impedi-lo de continuar fazendo parte do grupo. Nesse ponto, evidencia-se o boicote aos reais militantes que começavam a incomodar certa facção partidária. Era alguém que começava a incomodar seus superiores por perceber atitudes de corrupção, ou seja, alguém que tentava resgatar os ideais do antigo MPLA:

\footnotetext{
- Lá em cima precisam se livrar desse antigo camarada, hoje um traidor. nossa vergonha nacional. Um traidor entre vários outros, mas certamente o mais perigoso. Infelizmente ainda não se reuniram as provas suficientes para haver um processo criminal. O primeiro passo é retirá-lo do comitê central. Depois, com ele enfraquecido por já não pertencer à direção, é muito mais fácil fazer investigações profundas e descobrir todas as provas necessárias. Temos de reforçar a disciplina interna, limpar o partido das ervas daninhas. há um grupo de traidores que põem em perigo a própria sobrevivência do partido e mesmo a unidade da nação (PEPETELA, 2008, p. 326-327).
} 
Uma vez que o político que age eticamente é considerado como um traidor, não da pátria, mas dos esquemas ilicitos que marcam as ações governamentais, notamos mais uma vez a explícita crítica ao MPLA, partido do qual o próprio Pepetela fez parte, até a década de 1980. Retirar a força política daquele que age com ética significa justamente anular sua capacidade interventiva, prática naturalizada por aqueles que se beneficiavam por meio da corrupção.

Caposso, apesar de participar da conspiração, não tem seu nome indicado para a Central do Comitê do partido. Sua primeira derrota já nos indica que são muitos os predadores a darem o bote a qualquer momento. Embora poderoso, Caposso não era intocável e deveria utilizar-se de diferentes subterfúgios para sobreviver.

Pouco tempo depois, demite-se da direção e da Jota e decide estabelecer-se como grande capitalista:

Depois do famigerado congresso, sem se aperceber, começava a procurar pela primeira vez uma coerência entre os principios que defendia e a sua própria prática. Era um pequeno-burguês e o sonho de um pequeno burguês é tornar-se um grande burguês, acumular capital, explorar o povo. O objetivo era lançar-se em outros negócios, expandir os capitais, ser um grande capitalista a sério. Não precisava mais da máscara socialista, ele e muitos do MPLA, os verdadeiros visionários (PEPETELA, 2008, p. 244).

Conhece, em seguida, o empresário paquistanês Karim, disposto a lhe fornecer mercadorias para um minimercado, e o lobista norte-americano Omar, que se torna sócio em outro empreendimento, a construtora Caposso Trade Company. Ainda não satisfeito, animado por um general da ativa, ingressa no comércio clandestino de armas que alimentaria a guerra civil dos paises vizinhos e que seriam pagas com diamantes.

Estaria, portanto, no núcleo da juventude do partido grande parte da elite governante eclodiria nas primeiras décadas de independência. A caracterização do protagonista denuncia não apenas as situações de oportunismo no ambiente orquestrado para a criação do novo homem, como a implosão operada por esses indivíduos à própria ideia de nação assumida pelo Movimento e difundida às populações. No entanto, ideologicamente,

[...] o MPLA dialoga com a população tendo como via de expressão a ideia nacional, mas não uma ideia baseada a partir do reconhecimento e de análise da diversidade cultural existente, mas sim propondo um novo ideal em que a diversidade se enquadrasse, utilizando-se de um artefato acima de tudo político, e não necessariamente cultural, o homem novo (ARAÚJO, 2005, p. 77. grifo da autora).

A ascensão profissional do personagem encontra-se intimamente relacionada ao partido político dominante, embora tivesse sido caracterizado, no início do romance, como um jovem avesso à política. Vladimiro Caposso passa, através de golpes políticos e desta cadeia estabelecida de favores, de "camarada diretor, pois não havia outro tratamento possivel nos tempos do partido único, todo constituido por camaradas" (PEPETELA, 2008, p. 17) a chefe, pois, "o termo camarada, tão prático nas relações humanas, foi abruptamente banido". Caposso era patrão, "termo que, no entanto, trazia conotações negativas do tempo colonial, ninguém ousava utilizar. Chefe resolvia perfeitamente o problema". (PEPETELA, 2008, p. 18).

Sobre tal fato, Benedict Anderson mostra-nos que os vitoriosos sempre herdam a estrutura e o funcionamento do sistema anterior, pois:

Tal como a complexa rede elétrica de uma grande mansão depois que o dono vai embora, o Estado espera que o novo dono ligue os interruptores para voltar a funcionar com o antigo brilho. Portanto, não surpreende muito que as lideranças revolucionárias, consciente ou inconscientemente, venham a se fazer de senhores da mansão. Dessa acomodação surge invariavelmente aquele maquiavelismo de "Estado" que é um traço tão marcante nos regimes pós-revolucionários, em contraste com os movimentos nacionalistas revolucionários (ANDERSON, 2008, p. 222-223).

A obra segue apresentando a opressão imposta pelo protagonista a grupos marginalizados quando Caposso registra em seu nome a Fazenda Karan, 
grande faixa de terra nas proximidades de Huila. Outrora, a água do rio Culala corria livremente pelos terrenos e caminhos da região. Com chegada triunfal de Caposso, que logo se apossou da água, como proprietário da natureza, os pastores da região foram duramente prejudicados.

Caposso ordenou, despoticamente, a construção de uma represa que prejudicou o resto da população da área circundante, usurpando a água das plantações, para o gado e, consequentemente, para a subsistência da população. As terras adquiridas, para Caposso, representavam o sucesso de sua biografia burguesa.

Contrariamente aos pastores, Caposso via na Fazenda Karan apenas uma forma de ostentar sua riqueza, não uma forma de sobrevivência:

\begin{abstract}
Estes bois estão aqui para que o seu proprietário uma vez por mês venha lavar os olhos, contemplar o espetáculo, mostrar aos amigos, vêem estas terras a perder de vista, veem estas manadas que nunca mais acabam, isto tudo é meu. Nem vende a carne, nem se digna a recolher $o$ leite, apenas uns litros de vez em quando. Fica um fim-de-semana, feliz com sua riqueza e capacidade de a ostentar, pega no avião e nos amigos, volta com eles para Luanda (PEPETELA, 2008, p. 123).
\end{abstract}

É nessa etapa da vida de Caposso que novamente entra em cena Sebastião Lopes. Agora advogado da ONG Defesa dos Criadores Tradicionais (DECTRA), alia-se ao amigo Bernardino Chipengula, ativista local, e sai em defesa dos pastores das propriedades vizinhas à de Caposso, que passaram a ter suas passagens impedidas pela região após a instalação de uma enorme cerca:

\begin{abstract}
Chipengula e ele tornaram-se amigos na cadeia. Em 1976, quando se encontraram na prisão de São Paulo, acusados do mesmo crime, pertencerem a um comitê clandestino que considerava o governo demasiado de direita, desinteressado de fazer uma verdadeira revolução socialista. [...] Foram soltos ao mesmo tempo e Chipengula voltou à sua Huila natal. Trabalhou, estudou, acabando por se formar em História (PEPETELA, 2008, p. 130-131).
\end{abstract}

Sebastião Lopes está fora dos centros de poder político e econômico e defende os criadores tradicionais de gado em uma ação contra o empresário e fazendeiro Vladimiro, que adquiriu terras na Huila de maneira escusa, visto que era parte dos núcleos que faziam girar a roda do poder. Simboliza, assim, o herói que não se deixou corromper pelo sistema e cujo abandono do partido como militante possibilitou conscientizar-se de que o homem novo foi um projeto frustrado, visto que o novo homem se tornou o modelo de sucesso nos novos tempos, como predador da própria nação:

O meu trabalho é pacíico, só quero o bem destas pessoas. Acredito no gênero humano. Não são maus por natureza. O sistema é que os estraga. O homem é o lobo do homem, dizia o Hobbes: uma terra maravilhosa. Mas destinada à miséria (PEPETELA, 2008, p. 136)

Sebastião Lopes representa um antigo crente e membro do MPLA, decepcionado com o rumo que o país tomou após a revolução. O narrador indica-nos que, desiludido com o rumo que - MPLA tomou, Sebastião Lopes optara por abandonar o partido:
Sebastião foi tentando inscrever-se em Direito. As primeiras tentativas foram in- frutiferas, porque, embora as matriculas na universidade fossem na época livres e com pouca clientela, havia restrições para o novo curso de Direito, onde se forjaria a futura classe política, a qual deve ser coesa e de total confiança do governo. E ele tinha estado detido por inconfessáveis razões políticas. Foi preso por estar a distribuir panfletos subversivos aos soldados, panfletos que demonstravam a pouca consistência das promessas socialistas do MPLA e a necessidade de se formarem comitês clandestinos de militares para fazerem uma verdadeira Revolução. À terceira tentativa, conseguiu entrar no curso de Direito com ajuda do pai, outrora olheiro dos portugueses, hoje já oficial superior da polícia (PEPETELA, 2008, p. 128).

Na encenação dessa disputa entre Caposso e os criadores de gado, são importantes os levantamentos feitos acerca do abandono dos dirigentes quanto às questões territoriais, fator de intensas tensões e disputas antes mesmo do periodo colonial, visto que envolve práticas tradicionais de subsistência e de organização sociocultural. Segundo Bernardino Chipengula: 
E o MPLA veio e disse, cortem o arame, a terra é do povo. Gostei. Vinte e tal anos depois começam a vir os mesmos para fechar os pastos e os caminhos com arame farpado. Acreditávamos então em princípios... Bons e inocentes tempos... Centralizaram o poder em nome do bem comum, mas nada distribuíram para o povo angolano (PEPETELA, 2008, p. 131).

De acordo com a fala do personagem, houve um tempo em que se acreditou no povo como representante máximo da nação, esperança que não viria a se concretizar. Em um primeiro momento, o MPLA sinalizou que distribuiria as terras ao povo, em seguida, cercou as mesmas terras em defesa do direito à propriedade privada, obedecendo aos interesses empresariais:

- Estas são terras de direito costumei-
ro, de séculos e séculos, escaparam
das rapinas coloniais. Ok, eu sei, não
podemos impedir que empresários se
estabeleçam, as terras dão para muita
coisa. Mas não podem barrar os cami-
nhos naturais da transumância. O Culala
tem de voltar a correr para alimentar
esta gente toda que se fixou ao longo
dele e precisa da água não só para e
beber e para o gado, mas também para
irrigar as nakas de milho ou massango
e os legumes (PEPETELA, 2008, p. 139).

O trecho evidencia os efeitos do avanço capitalista não apenas nas zonas urbanas, mas também no interior, visto que nem mesmo durante o período colonial anterior ao século XX houve ação exploratória tão invasiva na região. O ativista explicita as dificuldades enfrentadas pelos trabalhadores rurais diante da limitação do acesso às aguas:

$$
\begin{aligned}
& \text { - Bois burgueses... } \\
& \text { Chipengula riu uma gargalhada gostosa. } \\
& \text { Os bois já estavam magros e ainda não } \\
& \text { tinha começado a estação seca. Os raros } \\
& \text { que tinham visto desde que abando- } \\
& \text { naram a estrada eram muito diferentes } \\
& \text { dos gordos e luzidios da fazenda. Estes } \\
& \text { eram de fato bois proletários, pensou } \\
& \text { Sebastião, para usar a linguagem de tem- } \\
& \text { pos passados (PEPETELA, 2008, p. 138). }
\end{aligned}
$$

Os proletários, com seus bois magros, não tinham as mesmas condições de sobrevivência de Caposso, embora esse não tratasse a fazenda como um meio de subsistência, mas sim de pura ostentação. Mais uma vez a cadeia predatória é representada, visto que se trata dos recursos disponiveis para a sobrevivência, precários para uma grande maioria e fartos para os poucos privilegiados. Ainda que com origens e com trajetórias próprias, Sebastião e Bernardino compartilham tanto o desencanto político quanto algum ânimo utópico, visto que se unem contra a ação de um predador maior que teria, inicialmente, todas as condições para vencê-los.

Apesar de parecer que não haveria chance na ação movida pelos criadores, Caposso é pressionado pela Justiça, e se vê obrigado a recuar diante da ação incisiva e justa de Sebastião Lopes, em articulação com os trabalhadores prejudicados. Surpreendentemente são auxiliados por Ivan, filho de Caposso, que acaba por reconhecer a injustiça feita pelo pai e abraça a causa da ONG, salvando Bernardino de uma emboscada.

A derrocada de Caposso começa a ser assinalada a partir do desgaste de sua ação predatória, seja devido ao avanço de outros predadores maiores, seja devido ao acúmulo de falcatruas já não toleradas. A recusa por parte dos bancos em conceder empréstimos a Caposso, decorrente dos gastos supérfluos e das dividas crescentes, marca o eclodir da esperança em outros tempos:
VC apresentou o projeto a todos os bancos e nenhum aceitou emprestar dinheiro. Eainda tinham o descaramento de dizer que os bancos estavam ai para ajudar o desenvolvimento do país [...]. É verdade que tinha gasto uma parte nos excessos suntuosos que cometia fora de Angola, sobretudo as fortunas que tinha perdido em noites de loucura nos cassi- nos ou nos cabarés mais afamados ou até o despautério aparatoso do casamento. Aparentemente esse senhor perdeu posi- ções e prestígio, têm aparecido algumas pessoas a se queixarem de grossas fal- catruas (PEPETELA, 2008, p. 321).

Quando recorreu a antigos amigos políticos, descobriu que para eles não era mais vantajoso aliar-se a grandes devedores envolvidos em falcatruas cada vez mais descaradas: 
Os governantes agora evitavam favorecer Caposso. E mais adiante: o próprio ministro das finanças, o qual tinha estado na inauguração da fazenda, seu amigo de muitos anos, companheiro de mulheres e de copos, ele próprio disse com um ar condoído, não posso fazer nada ficaria muito mal se pressionasse algum banco para te fazerem um empréstimo, os tempos são outros, bem sabes, os jovens maus andam reclamando dos pobres governantes, é a nova moda (PEPETELA, 2008, p. 324).

A Fazenda Karan poderia ser mantida, desde que não prejudicasse o curso da água, ou seja, seus caprichos começavam a ser publicamente contrariados. Nas últimas cenas de Caposso, o narrador situa-o na Fazenda Karan, juntamente aos familiares. O espaço será simultaneamente uma espécie de castigo e alento para as decepções sofridas, visto que só resta amargar a grande faixa de terra perdida após as negociações, bem como suas outras propriedades em locais "prestigiados", vendidas para pagamentos de dividas. Segundo ele,

Os novos donos do país têm necessidade absoluta de meter alguma ordem no circo, de parecer defender a legalidade, para poderem continuar a comer do melhor que os pais acumularam ilicitamente. Assim engorda um tubarão... Essa é a lei da vida (PEPETELA, 2008, p. 376, grifo nosso).

Devido ao desgaste após tantos abusos grosseiros de poder, ao acúmulo de dividas e à pressão de predadores maiores, os estrangeiros e até então parceiros, Karim e Omar, Caposso finalmente é abatido pela própria lei selvagem que o levou ao topo. "O problema de Caposso é que havia tubarões mais gordos ou mais fortes" (PEPETELA, 2008, p. 321): seus próprios sócios tomam-lhe a maior parte das ações da Caposso Trade Company. Conclui, assim, que "os estrangeiros sempre vieram para nos lixar. para lixar o negro. Sempre, sempre..." (PEPETELA, 2008, p. 73), cinicamente desconsiderando sua própria postura exploratória.

De acordo com a lógica mercadológica, temos em Vladimiro uma figura de aparente sucesso, visto que conseguiu adaptar-se totalmente à lei do mais forte, segundo os paradigmas neoliberais.
Sua derrocada, entretanto, ocorre justamente devido às crises inerentes ao sistema que o colocou no topo dos jogos de corrupção e de apropriação dos bens públicos pelo poder privado.

\section{Considerações finais}

O estudo da transposição metafórica da passagem do homem novo para o novo homem indica-nos a complexidade que envolve a caracterização subjetiva do individuo no pósindependência: Caposso jamais fora um homem novo, visto que forjou sua trajetória política, assim como não consegue se estabelecer como novo homem, pois é devorado por predadores maiores. As duas concepções de sujeito, portanto, mostram-se como categorias construídas e insuficientes, visto que não acompanham a dinamicidade das modificações sociais, bem como as particularidades que envolvem a (trans) formação dos cidadãos angolanos.

Embora o tom do romance seja predominantemente crítico, a queda de Caposso, representante de uma "elite emergente e fanfarrona" (PEPETELA, 2008, p. 294) ocorre quando Sebastião Lopes retorna à sua vida para defender os criadores de gado da Huila. Nesse ponto da obra, o outrora revolucionário não tem mais a inocência utópica da juventude, mas ainda é capaz de acreditar na construção de uma sociedade melhor e tem sucesso em sua ação contra Vladimiro de forma totalmente lícita. A desilusão provocada por princípios utópicos não modificou os valores de Sebastião Lopes, fator essencial para que pudesse derrotar Vladimiro quanto à proteção dos trabalhadores rurais.

A ação predatória é, portanto, flutuante, uma vez que varia de acordo com a chegada ou com a saída de novas figuras. Assim como o homem novo é um projeto defasado, o novo homem também o é, embora ainda se insista nesse modelo. Por meio de sua obra, Pepetela vislumbra a edificação de negociações representacionais, pautadas por um olhar sarcástico, mas ainda esperançoso na evolução dos sujeitos angolanos sob a perspectiva do bem comum, efetivamente a construção de uma Angola por e para angolanos. 
A literatura, como espaço de questionamento, torna-se um campo privilegiado para a construção de novas possibilidades interpretativas. Também é locus privilegiado para se compreender os intercâmbios e repercussões que ocorrem a partir dos processos históricos e políticos de Angola. Após a análise de Predadores, fica patente que ainda há o desejo, expresso pela literatura, de se construir uma Angola para o povo angolano. Nesse sentido, Pepetela não se dedica à construção de um outro modelo de sujeito, mas sim à atualização crítica e infindável da sociedade angolana como principal via para a projeção de identificações ligadas a sujeitos que de fato ressignifiquem a utopia e, consequentemente, a luta por transformações.

\section{Referências}

ANDERSON, Benedict. Comunidades Imaginadas. Tradução de Denise Bottman. São Paulo: Companhia das Letras, 2008.

ARAÚJO, Kelly Cristina Oliveira. "Um só povo, uma só nação": o discurso do Estado para a construção do homem novo em Angola (1975-1979). Dissertação (Mestrado) - Programa de Pós-Graduação em História da Faculdade de Filosofia, Letras e Ciências Humanas de São Paulo, São Paulo, 2005.

BARBEITOS, Arlindo. A sociedade civil: estado, cidadão e identidade em Angola. Lisboa: Novo Imbondeiro, 2006.

CHAVES, Rita. A formação do romance angolano: entre intenções e gestos. São Paulo: Coleção Via Atlântica, 1999.

FANON, Frantz. Os condenados da terra. Tradução de José Laurênio de Melo. Rio de Janeiro: Civilização Brasileira, 1979.

FRADE, Ana Maria Duarte. A Corrupção no Estado Pós-Colonial em África: duas visões literárias. Porto: Edições Eletrónicas CEAUP, 2007. Disponivel em: https://www.africanos.eu/images/publicacoes/livros_ electronicos/EBo02.pdf. Acesso em: 21 set. 2019.

FROMM, Erich. O conceito Marxista do Homem. Tradução de Octavio Alves Velho. Rio de Janeiro: Zahar, 1962.

GONÇALVES, António Custódio. Tradição e Modernidade na (Re) Construção de Angola. Porto: Edições Afrontamento, 2003.

GONÇALVES, António Custódio. A história revisitada do Kongo e de Angola. Lisboa: Estampa, 2005.

MARX, Karl; ENGELS, Friedrich. A ideologia alemã. São Paulo: Martins Fontes, 1998.
MATA, Inocência. Ficção e História na literatura angolana: o caso de Pepetela. Edições Colibri: Lisboa, 2010.

MUDIMBE, Valentin. Yves. A ideia de África. Luanda: Edições Mulemba, 2012.

MBEMBE, Achile. Crítica da razão negra. Lisboa: Antígona, 2014.

NETO, Agostinho. Discurso da independência de Angola. [S. l: s. n.]: 1975. Disponivel em: https://www. governo.gov.ao/. Acesso em: 21 set. 2019.

PEPETELA. A geração da utopia. Lisboa: Dom Quixote, 1997.

PEPETELA. Predadores. Rio de Janeiro: Língua Geral, 2008.

RUI, Manuel. Angola, avante. [S. L.: s. n.]: 1975. Disponivel em: https://www.governo.gov.ao/. Acesso em: 21 set. 2019.

VENÂNCIO, José Carlos. Multiculturalismo e literatura nacional em Angola. In: GONÇALVES, António Custódio. Multiculturalismo, Poderes e Etnicidades na África Subsariana. Porto: Faculdade de Letras/Centro de Estudos Africanos da Universidade do Porto, 2002.

\section{Endereço para correspondência}

Mariana Sousa Dias

Rua Dionisio Erthal, 36, apto. 401

Santa Rosa, 24240-020

Niterói, RJ, Brasil 